\title{
Analisis Pengelolaan Trias Usaha Kesehatan Sekolah (UKS) di Tingkat SMP Se-Kota Bandar Lampung (Studi Kualitatif)
}

\author{
Nana Novariana ${ }^{1}$, Nur Sefa Arief Hermawan ${ }^{2}$ \\ ${ }^{1,2}$ Jurusan Kesehatan Masyarakat, STIKES Mitra Lampung, Indonesia \\ Email: nnovariana@yahoo.com
}

\begin{abstract}
Analysis of Trias Management of School Health Efforts (UKS) at Junior High School Level in Bandar Lampung City (Qualitative Study). School Health Effort Programs held at all levels of education. The purpose of School Health Efforts was to improve the quality of education and learning achievement of learners by improving the behavior of clean and healthy life and health status and create a healthy environment, thus allowing harmonious growth and optimum development in the framework of human formation in Indonesia as a whole. The purpose of this research was to analyze more deeply about the management of Trias School Health Efforts (UKS) at Junior High School level in Bandar Lampung City in 2017. This research was a qualitative research type with descriptive analysis research design with phenomenology approach. The study was conducted from March to April 2017 at the Junior High School level in Bandar Lampung city, the Office of the Ministry of Religious Affairs of Bandar Lampung City, the Bandar Lampung City Health Office, and the Education Office of Bandar Lampung City. With informants, 31 informants from headmasters, UKS teachers, and UKS officers, and staff organizing UKS at Health Office, Education Office, and Ministry of Religious Affairs. The conclusion of the research result was that in general tries of UKS in junior high school level as Bandar Lampung City has been running quite well, both in terms of health education, health service, and healthy environment coaching. It was just that in each of the triads still need more and more coaching. As well as from the Community Health Centres can further channel the new sciences that have been obtained for more fostering schools that exist within the target area.
\end{abstract}

Keywords: Trias of School Health Effort (UKS) Management

\begin{abstract}
Abstrak: Analisis Pengelolaan Trias Usaha Kesehatan Sekolah (UKS) di Tingkat SMP SeKota Bandar Lampung (Studi Kualitatif). Usaha Kesehatan Sekolah (UKS) dilaksanakan pada semua tingkatan pendidikan. Tujuan UKS adalah meningkatkan mutu pendidikan dan prestasi belajar peserta didik dengan meningkatkan perilaku hidup bersih dan sehat serta derajat kesehatan dan menciptakan lingkungan yang sehat, sehingga memungkinkan pertumbuhan dan perkembangan yang harmonis dan optimal dalam rangka pembentukan manusia di Indonesia seutuhnya. Tujuan penelitian untuk menganalisis lebih mendalam tentang pengelolaaan trias UKS di Tingkat SMP se-Kota Bandar Lampung tahun 2017. Penelitian menggunakan jenis penelitian kualitatif, desain penelitian analisis deskriptif dengan pendekatan fenomenologi. Penelitian dilakukan pada Maret-April 2017 bertempat di tingkat SMP se-kota Bandar Lampung, Kantor Kementrian Agama Kota Bandar Lampung, Dinas Kesehatan Kota Bandar Lampung, dan Dinas Pendidikan Kota Bandar Lampung. Informan berjumlah 31 orang dari Kepala sekolah, guru pembina UKS dan petugas UKS, serta pegawai yang memegang pelaksanaan UKS di Dinas Kesehatan, Dinas Pendidikan, dan Kementrian Agama. Secara umum trias UKS di tingkat SMP se-Kota Bandar Lampung sudah berjalan cukup baik seperti pada pelayanan kesehatan maupun pembinaan lingkungan sehat, hanya pada pendidikan kesehatan masih perlu peningkatan pembinaan. Seperti halnya dari pihak puskesmas dapat lebih menyalurkan ilmu-ilmu baru yang telah didapat untuk lebih membina sekolah-sekolah yang ada dalam wilayah binaannya.
\end{abstract}

Kata kunci: Pengelolaan trias Usaha Kesehatan Sekolah (UKS)

Program UKS dilaksanakan pada semua jenis atau tingkatan pendidikan, baik Sekolah Negeri maupun Swasta mulai dari tingkat Sekolah Dasar hingga Sekolah Menengah Atas. Tujuan UKS ini adalah meningkatkan mutu pendidikan dan prestasi belajar peserta didik dengan meningkatkan perilaku hidup bersih dan sehat serta derajat kesehatan peserta didik dan menciptakan lingkungan yang sehat, sehingga memungkinkan pertumbuhan dan perkembangan yang harmonis dan optimal dalam rangka 
pembentukan manusia Indonesia seutuhnya. (Kemenkes, 2011).

Trias UKS terdiri dari Pendidikan

Kesehatan, Pelayanan Kesehatan, dan Lingkungan Sekolah yang sehat. Keberhasilan pelaksanaan trias UKS yang baik, dirasa sangat mempengaruhi dalam keberhasilan peningkatan derajat kesehatan di lingkungan sekolah. Masalah-masalah yang dapat muncul karena kurang terlaksana dengan baiknya trias UKS adalah seperti meningkatnya perilaku merokok di lingkungan sekolah oleh peserta didik, adanya pemakaian NAPZA dan meningkatnya perilaku seks bebas serta HIV/AIDS.

Didapatkan data menurut Riskesdas 2013, perilaku merokok penduduk usia 15 tahun keatas masih belum terjadi penurunan dari 2007 sampai dengan tahun 2013 cenderung meningkat dari $34,2 \%$ menjadi $36,3 \%$. Dimana $64,9 \%$ laki-laki dan $2,1 \%$ perempuan masih menghisap rokok. Ditemukan $1,4 \%$ dari jumah tersebut adalah perokok usia 10-14 tahun. Hal ini dapat memicu meningkatnya angka kejadian penyalahgunaan narkoba oleh remaja, yakni didapatkann data secara global, jumlah remaja (10-12 tahun.) sebesar 25 persen atau 1,8 miliar dari jumlah penduduk. Hasil Sensus Penduduk 2010 menunjukkan bahwa secara nasional jumlah ramaja mencapai 64 juta atau 27,6 persen dari total penduduk Indonesia. Jumlah tersebut merupakan yang tertinggi dalam sejarah demografi Indonesia, dan akan terus meningkat sampai dengan tertutupnya bonus demografi. Kenyataan lain juga menunjukkan bahwa remaja Indonesia semakin terlibat dalam penyalahgunaan narkoba/NAPZA. Data Badan Narkotika Nasional (BNN) menunjukkan bahwa pada 2012 jumlah pengguna NAPZA dikalangan remaja mencapai 3,6 juta orang, kemudian meningkat 3,8 juta orang pada 2013. Jika tidak dilakukan pencegahan, jumlahnya akan mencapai 5 juta lebih pada tahun 2016 .

Didapatkan juga data penderita HIV sejak 2011-Oktober 2015, yaitu tahun 2011 sebanyak 130 kasus, tahun 2012 sebanyak 383 kasus, tahun 2013 sebanyak 185 kasus, tahun 2014 sebanyak 256 kasus, dan tahun 2015 sebanyak 344 kasus. Sedangkan untuk penderita AIDS sejak 2011- Oktober 2015, yaitu tahun 2011 sebanyak 22 kasus, tahun 2012 sebanyak 53 kasus, tahun 2013 sebanyak 94 kasus, tahun 2014 sebanyak 81 kasus, dan tahun 2015 sebanyak 128 kasus. Sebagian besar dari jumlah itu adalah remaja usia 15-24 tahun yang berada di kota Bandar Lampung (Dinkes Provinsi Lampung, 2014).

Beberapa hasil penelitian tentang pelaksanaan trias UKS menunjukkan bahwa pelaksanaan trias UKS masih belum maksimal, Ramawati (2007) dalam penelitian yang dilakukan di SMP wilayah Purwokerto 23,72\% responden tidak melaksanakan pelayanan kesehatan dari Puskesmas di sekolah dan 59,03\% responden mengatakan tidak ada pencatatan khusus bagi siswa yang tidak masuk karena masalah kesehatan/penyakit menular. Begitu juga dengan penelitian (Sitepu, dkk, 2015) dalam penelitian yang dilakukan di SMP Negeri 1 Manado mendapatkan hasil hambatan dalam pelaksanaan UKS di sekolah ini adalah karena kurang berjalannya program kemitraan yakni kurangnya kunjungan Puskesmas dalam pemberian sosalisasi pada warga sekolah. Di Kota Bandar Lampung, UKS dipandang belum bergerak atau dimanfaatkan secara maksimal oleh masing-masing sekolah.

\section{METODE}

Penelitian ini menggunakan jenis penelitian kualitatif dengan desain penelitian survei analisis dengan pendekatan fenomenologi karena penelitian ini berusaha untuk memahami subjek penelitian dari sudut pandang pihak yang terlibat dalam pelaksanaan trias UKS itu sendiri sehingga peneliti dapat memahami tentang bagaimana pelaksanaan trias UKS yang telah dilakukan. Pada pengambilan data ini, informan hanya dilakukan satu kali wawancara, karena untuk menghindari bias informasi. Subjek penelitian sebagai sumber informasi dipilih secara purposive.

Pengamatan dan pencatatan dilakukan dengan mengajukan pertanyaan atau wawancara serta FGD, dan analisis dokumen yang berkaitan dengan tugas informan dalam pelaksanaan trias UKS di Tingkat SMP se-Kota Bandar Lampung. Wawancara mendalam (Indepth Interview) (Kepala Sekolah, Guru Pembina UKS, Petugas UKS, Tim Pembina UKS Kementrian Agama Kota Bandar Lampung, Tim Pembina UKS Dinas Kesehatan Kota Bandar Lampung, dan Tim Pembina UKS Dinas Pendidikan Kota Bandar Lampung) dan FGD (Siswa/i kelas 1 dan 2) dilakukan untuk dapat menggali lebih dalam informasi dari informan, digunakan untuk proses pengumpulan data dan dilaksanakan dengan bantuan instrumen berupa kuesioner atau pedoman wawancara yang telah disusun dan disiapkan sebelumnya serta dibantu dengan alat tulis dan alat rekam suara. Pada pelaksanaan wawancara mendalam, suasana pembicaraan diupayakan seakrab mungkin agar seluruh informasi dapat tergalih dengan jelas. 
Metode pengumpulan data yang Peneliti gunakan adalah dengan menggunakan pedoman wawancara mendalam, lembar FGD, ceklist lembar observasi serta telaah data sekunder yakni berupa dokumen-dokumen resmi terkait untuk memperoleh fakta mengenai hal yang diteliti yaitu analisis pelaksanaan trias UKS di Tingkat SMP se-Kota Bandar Lampung. Adapun jenis wawancara yang digunakan peneliti adalah wawancara menggunakan pertanyaan terbuka kepada informan yakni dilakukan dengan tujuan untuk memperoleh informasi mendalam tentang bagaimana pelaksanaan trias UKS selama ini dilakukan dan melakukan cross check atas informasi yang diperoleh dari subjek dan sekaligus sebagai informasi pendukung melalui lembar observasi dan dokumen-dokumen resmi lainnya.

Dalam penelitian ini, peneliti menggunakan teknik triangulasi. Adapun macam triangulasi tersebut meliputi triangulasi berbagai sumber, triangulasi berbagai metode, dan triangulasi teori.

\section{HASIL}

Informan pada penelitian ini orang-orang yang dianggap mampu memberikan penjelasan tentang UKS. Informan dalam penelitian ini dibagi menjadi dua, yakni pertama adalah informan utama yang terdiri dari pengelola UKS pada dinas pendidikan, pengelola UKS pada dinas kesehatan dan pengelolaan UKS pada kementerian agama, serta melibatkan pengelola UKS. Masing-masing sekolah dalam penelitian ini terdiri dari kepala sekolah 1 orang, guru pembina UKS 1 orang, petugas UKS 1 orang, siswa-siswi sekolah tersebut sebanyak 2 kelompok. Dan yang kedua adalah informan ahli, yakni pembimbing 1 dan pembimbing 2 peneliti dalam penelitian ini.

Berdasarkan uraian hasil dalam wawancara mendalam, maka dapat dikelompokkan hasil seperti dalam tabel berikut:

Tabel 1. Uraian Hasil Wawancara Mendalam

\begin{tabular}{|c|c|c|}
\hline & Uraian hasil & $\begin{array}{l}\text { Simpulan } \\
\end{array}$ \\
\hline \multirow[t]{5}{*}{ Input } & SK Tim Pembina & $\begin{array}{l}\text { Seluruh pelaksana menyatakan bahwa mereka memiliki } \\
\text { SK Tim Pembina UKS. }\end{array}$ \\
\hline & $\begin{array}{l}\text { Alasan dipilihnya sebagai anggota } \\
\text { Tim Pembina }\end{array}$ & $\begin{array}{l}\text { Dilihat dari pengalaman orang-orang yang sudah biasa } \\
\text { tangani UKS. }\end{array}$ \\
\hline & $\begin{array}{l}\text { Pelaksanaan pendidikan kesehatan } \\
\text { bagi sekolah }\end{array}$ & $\begin{array}{l}\text { Masing-masing bidang memegang peranannya masing- } \\
\text { masing, seperti dibidang agama, kesehatan dan } \\
\text { pendidikan. Selain itu mereka membina sesuai dengan } \\
\text { tugas pokok dan fungsinya. }\end{array}$ \\
\hline & Kontrol dari kementrian/kedinasan & $\begin{array}{l}\text { Masing-masing bidang mengontrol masing-masing } \\
\text { sekolah melalui kepala sekolahnya. Sehingga apapun } \\
\text { kekurangannya dapat segera diketahui. }\end{array}$ \\
\hline & $\begin{array}{l}\text { Jadwal khusus untuk pembinaan } \\
\text { sekolah }\end{array}$ & $\begin{array}{l}\text { Masing-masing bagian memilikik program kerja yang } \\
\text { sudah tersusun rapih hanya saja masih ada kendala } \\
\text { masalah waktu }\end{array}$ \\
\hline
\end{tabular}

\begin{tabular}{ll}
\hline Proses & Pendidikan Kesehatan \\
& Pelaksanaan pendidikan kesehatan \\
& di sekolah binaan
\end{tabular}

Keberadaan petugas khusus untuk pendidikan kesehatan

Cara yang dilakukan dalam pemberian pendidikan kesehatan.

Dana khusus untuk pendidikan kesehatan
Untuk pendidikan kesehatan diserahkan langsung pada masing-masing sekolah. Karena masing-masing dinas dan kementrian sudah mempercayakan pada sekolah.

Masing-masing sekolah tidak memiliki petugas khusus, biasanya melalui petugas UKS, guru, atau kolaborasi dengan pihak ketiga.

Yakni dengan memberikan leaflet dan poster-poster kesekolah.

Ada dana khusus untuk kegiatan kesehatan sekolah, terutama untuk UKS sendiri. 
Cara mengetahui pendidikan

kesehatan dimengerti

Pembinaan kawasan "bebas rokok", narkoba dan minuman keras

\section{Pelayanan Kesehatan}

Proses pembinaan kepada petugas UKS

Pembinaan pengobatan darurat oleh guru UKS terlatih atau petugas

Pelaksanaan pembinaan dari puskesmas atau guru tentang konseling remaja oleh pendidik sebaya

Rujukan pengobatan bila ditemukan siswa terjangkit penyakit

Pelaksanaan P3K dan P3P oleh petugas UKS

Administrasi dalam pengobatan

Penganggaran dana kegiatan pelayanan UKS

Bentuk dukungan dari petugas Puskesmas

\section{Pembinaan Lingkungan Sekolah} Pemantauan mata siswa

Penyediaan sarana air bersih

Penjagaan kebersihan sarana air bersih

Pengawasan lingkungan bebas jentik nyamuk

Pembuangan limbah sekolah
Keberhasilan pendidikan kesehatan bisa diketahui dengan cara melihat dari kebersihan sekolah dan kepatuhan siswa dalam menjaganya.

Masing-masing sekolah ada dan itu dapat berjalan dengan baik, karena sesuai dengan target mereka yang menginginkan siswanya tidak jatuh pada penyalahgunaan narkoba maupun rokok.

Untuk pembinaan petugas UKS dilakukan oleh puskesmas pembina masing-masing wilayah disekolah.

Untuk pembinaan pengobatan darurat tidak terlalu banyak diperlukan kerena petugas sudah diambil dari background kesehatan.

Sudah pernah mendengar tentang program konseling remaja, hanya saja kendala ada pada ketersediaan SDM yang profesional.

Untuk tujuan rujukan, masing-masing sekolah sudah bekerja sama dengan puskesmas pembinanya, klinik terdekat, dan rumah sakit.

Untuk penanganan $\mathrm{P} 3 \mathrm{~K}$ dan $\mathrm{P} 3 \mathrm{P}$ oleh petugas UKS masing-masing sekolah sudah cukup baik.

Untuk pencatatan administrasi masing-masing sekolah sudah cukup baik.

Untuk dana semua sudah dimasukkan dalan anggaran APBD kesehatan.

Untuk pemantauan, masing-masing sekolah sudah ada pembina puskesmas, terutama untuk obat-obatan. Kementrian atau kedinas biasanya langsung datang kesekolah untuk pemantauan.

Dengan mengatur jarak pandang siswa kursi terdepan dengan papan tulis masing-masing sekitar 2 meter, dinas kesehatan memang sudah mengarahkan, tetapi semua tetap dikembalikan pada pihak sekolah.

Masing-masing sekolah sudah memiliki sumber air bersihnya sendiri. Seperti dengan sumur bor atau PAM.

Untuk penjagaan kebersihan terutama air bersih, masing-masing sekolah memiliki kegiatan "Jumat Bersih" yang rutin dilakukan sebanyak satu kali tiap bulannya.

Untuk bebas jentik nyamuk, masing-masing sekolah telah diberikan bubuk abate oleh masing-masing puskesmas pembina.

Masing-masing sekolah sudah memiliki saluran pembuangan limbah masing-masing yang memadai. Masing-masing sekolah juga memiliki tempat pembuangan sampah sementara. 
Penyimpanan peralatan UKS

Pengawasan kantin sekolah

Penyuluhan dan atau pengarahan tentang rokok, narkoba dan minuman keras
Masing-masing sekolah sudah memiliki ruang UKS sendiri. Sehingga dapat menyimpan peralatan sendiri.

Masing-masing sekolah sudah memantau kebersihan kantin sekolah. Beserta aturannya masing-masing.

Untuk pengarahan narkoba dan lain-lain, masing-masing sekolah sudah melaksanakan.

\begin{tabular}{lll}
\hline Output & $\begin{array}{l}\text { Pembinaan dalam pengawasan oleh } \\
\text { guru BP/BK dan atau wali kelas }\end{array}$ & $\begin{array}{l}\text { Untuk pemantauan siswa, kementerian dan kedinasan } \\
\text { sudah bekerja sama dengan sekolah melalui guru BK, } \\
\text { Wali Kelas dan guru-guru. }\end{array}$
\end{tabular}

Penerapan perilaku hidup bersih dan sehat di lingkungan sekolah

Mereka dan pihak sekolah sudah siap dalam penanganan penyakit, walaupun sejauh ini belum pernah ditemukan kasusnya.

Upaya evaluasi perihal kesehatan

Evaluasi pelaksanaan kesehatan dapat dilakukan dengan warga sekolah cara melihat derajat kesehatan warga sekolah melalui absen kehadiran.

Observasi Penilaian Lingkungan Sehat di Sekolah didapatkan hasil bahwa 4 sekolah dalam kondisi baik dan layak beroperasi, 1 sekolah dalam kondisi cukup, dan 1 sekolah dalam kondisi kurang baik, yakni dengan rincian sebagai berikut :

1. Atap dan talang memenuhi syarat dan tidak berpotensi terjadi kerusakan dan kebocoran

2. Dinding memenuhi syarat dan tidak berpotensi terjadi kerusakan

3. Lantai memenuhi syarat dan tidak berpotensi terjadi kerusakan

4. Tangga memenuhi syarat dan tidak berpotensi kerusakan

5. Pencahayaan ruang kelas memenuhi syarat

6. Pencahayaan ruang perpustakaan memenuhi syarat

7. Pencahayaan ruang laboratorium memenuhi syarat

8. Ventilasi memenuhi syarat

9. Kepadatan kelas memenuhi syarat

10. Jarak papan tulis dengan bangku terdepan minimal 2 meter

11. Jarak papan tulis dengan bangku terbelakang maksimal 9 meter

12. Ada sarana cuci tangan dan tersedia sabun

13. Tidak ada keluhan kebisingan

14. Kualitas air bersih baik

15. Kamar mandi memenuhi syarat

16. WC memenuhi syarat

17. Terdapat tempat sampah ditiap kelas

18. Memenuhi syarat

19. Tidak ditemukan vektor penyakit (lalat, jentik nyamuk, kecoa, dll)

20. Kantin sekolah memenuhi syarat kantin sehat

21. Halaman sekolah memenuhi syarat
22. Meja belajar siswa memenuhi syarat

23. Tidak ditemukan prilaku merokok, narkoba, dll

24. Kehadiran siswa selalu terpantau dari absen.

25. Siswa terpantau oleh walikelas.

\section{PEMBAHASAN}

\section{Pendidikan Kesehatan}

Menurut hasil penelitian pada Tim Pembina UKS di kementerian dan kedinasan didapatkan hasil bahwa mereka sudah menjalankan dan mengoptimalkan pendidikan kesehatan di sekolah yakni dengan cara memantau baik secara langsung maupun tidak langsung dalam pelaksanaan pendidikan kesehatan. Selain itu dalam pelaksanaan pelayanan kesehatan, Tim Pembina saling bekerja sama untuk memenuhi kriteria pemberi pelayanan yang terbaik, seperti dengan memberikan pemantauan terhadap ilmu-ilmu pelayanan seperti dalam penanganan penyakit, pemantauan program dan pemberian konseling pada remaja. Selain itu, pembinaan sistem rujukan juga menjadi pemantauan utama karena hal ini menjadi alternatif utama apabila puskesmas pembina tidak dapat mengatasi permasalahan. Sementara untuk pemantauan sekolah yang sehat dilakukan dengan adanya pemantauan kesehatan mata siswa, yakni dengan cara mengatur jarak pandang tempat duduk siswa kursi terdepan berjarak \pm 2 meter dengan papan tulis, selain itu sumber air di masing-masing sekolah sudah menggunakan sumur bor dimana tiap minggu bak penampungan dikuras dan 
diberikan bubuk abate agar tidak ada jentik-jentik nyamuk. Ada juga kegiatan yang dilakukan dalam satu bulan sekali untuk membersihkan lingkungan sekitar sekolah. Untuk pembuangan limbah dan pemantauan kantin sekolah sudah dilakukan dengan baik.

Menurut materi yang terdapat dalam Buku Panduan Tim Pembina, disampaikan bahwa dalam proses pelaksanaan trias UKS harus terpenuhi tiga hal yakni pendidikan kesehatan, pelayanan kesehatan, dan pembinaan sekolah yang sehat. Dalam pendidikan kesehatan merupakan upaya memberikan bimbingan kepada peserta didik untuk meningkatkan pengetahuan kemampuan dan keterampilan peserta didik dalam melaksanakan perilaku hidup dan sehat agar dapat tumbuh dan berkembang dengan baik, selain di bidang kesehatan peserta didik juga dibina dalam bidang kesehatan lingkungan yang merupakan bagian yang sangat mempengaruhi pembentukan pribadi peserta didik, adanya proses kenaikan bagi peserta didik maka harus menyelenggarakan kegiatan sosialisasi setiap tahun sehingga seluruh peserta didik terpapar materi kesehatan dan kesehatan lingkungan. Pembinaan kesehatan dilakukan secara intra kurikuler dan ekstra kurikuler. Kegiatan intra kurikuler adalah melaksanakan pendidikan pada saat jam pelajaran berlangsung sesuai dengan ketentuan yang berlaku. Pendidikan ini tidak hanya diberikan pada saat mata pelajaran Pendidikan Jasmani saja, namunbisa juga secara integratif pada saat mata pelajaran lainnya disampaikan kepada peserta didik. Kegiatan ekstrakurikuler adalah melaksanakan pendidikan di luar jam pelajaran yang dilakukan disekolah atau di luar sekolah. Misalnya, melaksanakan penyuluhan tentang, gizi, narkoba, dan sebagainya terhadap peserta didik, guru dan orang tua. Melaksanakan pelatihan UKS bagi peserta didik, guru pembina UKS dan kader kesehatan. Melaksanakan pendidikan dan kebiasaan hidup bersih melalui program sekolah sehat.

\section{Pelayanan Kesehatan}

Untuk pelayanan kesehatan meliputi kegiatan (promotif), latihan keterampilan teknis pemeliharan kesehatan dan pembentukan peran serta aktif peserta didik dalam pelajaran kesehatan, antara lain: Kader Kesehatan Sekolah, olahraga, kesehatan, berkebun dan lomba, pembinaan sarana lingkungan sekolah, antara lain (Pembinaan warung sekolah (kantin), lingkungan sekolah yang terpelihara, pembinaan keteladanan berperilaku hidup sehat), kegiatan pencegahan
(Preventif), Memelihara Kesehatan yang (Depkes, 2011) bersifat umum dan khusus, Penjaringan kesehatan bagi anak, Memonitoring/memantau peserta didik, Usaha pencegahan penyakit menular, Kegiatan penyembuhan dan pemulihan (kuratif dan rehabilitasi), diagnosa dini, pengobatan pada penyakit, P3K dan P3P.

\section{Pembinaan Sekolah Sehat}

Sedangkan untuk pembinaan sekolah sehat Menurut WHO adapun Pembinaan kepada peserta didik agar dapat menerapkan pentingnya UKS diantaranya dengan melaksanakan kegiatan sebagai berikut: melaksanakan kerja bakti kebersihan sekolah secara rutin dan terencana (Jumat bersih, piket kapling, piket kelas), melaksanakan kerja bakti dengan lingkungan masyarakat sekitar Sekolah, membuang sampah pada tempatnya dan pengadaan tempat sampah di depan kelas, dipilih antara sampah organik dan anorganik, mengolah sampah organik menjadi kompos, tidak mencorat-coret dinding dan bangku, menyiram jamban sampai bersih sesudah dipakai, membuat dan memelihara kapling, kebun sekolah, TOGA, taman sekolah, Mengikuti kegiatan dinamika kelompok (wisata, olah raga dan kesenian).

Menurut hasil penelitian Ramawati (2007) tentang pelaksanaan UKS, didapatkan hasil bahwa dalam pkegiatan pendidikan kesehatan hal yang harus diperhatikan adalah materi pembelajaran mengenai ilmu kesehatan, penyuluhan mengenai kesehatan, penyuluhan/ pelatihan kesehatan tentang: Tumbuh kembang fisik dan mental remaja, penyakit karena tidak menjaga kebersihan pribadi, bahaya narkotika, rokok, dan minuman beralkohol, pencemaran lingkungan dan pengaruhnya terhadap kesehatan, menjaga keselamatan diri, penyakit menular dan tidak menular, cara pencegahan dan penanggulangan penyakit serta pengobatan sederhana, Pertolongan Pertama pada Kecelakaan $(\mathrm{P} 3 \mathrm{~K})$, program kegiatan ekstrakulikuler yang berkaitan dengan pendidikan kesehatan. Untuk pelayanan kesehatan hal yang harus diperhatikan adalah Pemeriksaan kesehatan dari Puskesmas, Pelaksanaan senam bersama (SKJ), kegiatan ekstrakurikuler yang berkaitan dengan pelayanan kesehatan (latihan keterampilan (dokter kecil, PMR), membantu kegiatan Posyandu saat liburan sekolah, kegiatan pengobatan sederhana, Pemeriksaan kesehatan saat penerimaan murid baru, Pemantauan tumbuh kembang siswa secara periodik, Pemberantasan sumber penyakit infeksi, adanya konseling mengenai kesehatan 
remaja di sekolah, pencatatan khusus bagi siswa yang tidak masuk karena masalah kesehatan/penyakit menular. Sedangkan untuk pembinaan lingkungan sehat sekolah melalui Penyuluhan kesehatan, Pemasangan poster/media yang mempromosikan lingkungan sehat, Pemeliharaan kebersihan \& kerapihan sarana dan prasarana sekolah (ruang kelas, ruang perpustakaan, ruang laboratorium), Pemeliharaan lingkungan fisik sekolah yang menunjang kesehatan (penyediaan air bersih, penyediaan/ pemeliharaan bak sampah, penyediaan/ pemeliharaan $\mathrm{WC} /$ kakus, pemeliharaan ruang ibadah, pemeliharaan kebun/ taman sekolah), Lingkungan mental dan sosial yang menunjang kesehatan (bakti sosial dan darmawisata).

Berdasarkan analisis dapat ditarik kesimpulan bahwa ada keterkaitan antara hasil penelitian, materi terkait dan penelitian terkait. Dimana hal-hal yang menjadikan tolak ukur kesuksesan pelaksanaan UKS adalah dengan melalui tiga kegiatan yakni pendidikan kesehatan, pelayanan kesehatan, dan pembinaan sekolah sehat. Dimana masing-masing telah diuraikan. Dalam hal pelaksanaan kegiatan trias UKS, masing-masing ketiga kegiatan tersebut saling berkaitan dan berkesinambungan. Dimana hal yang menjadi kunci pokok adalah pada adanya anggaran yang menyokong kegiatankegiatan tersebut dan adanya struktur organisasi UKS yang jelas. Hal ini sebagai gambaran bahwa dengan adanya garis instruksi yang jelas, maka kegiatan UKS ini dapat berjalan secara maksimal dan lancar. Dengan adanya dana yang mencukupi, maka segala kegiatan terutama yang menyangkut kegiatan lapangan dapat selalu berjalan dengan baik.

Selain itu ketersediaan sarana dan perlengkapan juga menjadi hal yang tidak kalah penting, karena dengan adanya hal-hal yang mendukung tadi menjadikan kegiatan pelaksanaan UKS menjadi berjalan secara maksimal. Kegiatan UKS sendiri menjadikan penilaian derajat kesehatan sekolah menjadi terukur, terutama dalam kegiatan belajar mengajar, bila kondisi guru dan siswanya sehat baik secara badan dan pikiran, maka kegiatan belajar mengajar pun tidak akan ada kendala, begitupun dengan adanya kesehatan secara psikologis, bila kegiatan pelaksanaan UKS dapat kita berikan secara maksimal maka apa yang menjadi cita-cita dan harapan sekolah dapat terwujud dengan baik. Dalam hal ini penekanan pada pendidikan kesehatan reproduksi juga dirasa sangat penting, karena pada masa ini remaja perlu mendapatkan sumber informasi yang jelas, terpercaya dan dapat dipertanggung jawabkan.
Karena dengan adanya keterbukaan mereka kepada peran petugas kesehatan, maka dapat menyelamatkan mereka dari pengaruh buruk lingkungan dan pergaulan teman sebaya yang kurang baik. Hal ini dapat terjadi bila remaja mengalami krisis percaya diri bahkan dapat menuju pada kurang percaya diri dan bahkan tidak percaya diri. Bila hal ini sampai terjadi, masa depan remaja dapat menjadi pertaruhan yang tidak dapat dipertanggungjawabkan.

Dalam kegiatan pemantauan lingkungan sekolah yang sehat juga hal yang tidak dapat dilepaskan dari kegiatan sehari-hari pelaksanaan UKS, seperti halnya dalam pemantauan kesehatan dan kebersihan kantin sekolah, maka apa yang terlewatkan sebelumnya dapat terpantau dengan baik oleh sekolah. Karena dengan memantau kantin sekolah maka petugas dan guru-guru dapat memantau apa yang siswa-siswa konsumsi. Termasuk dapat pantau gizi dan kesehatan siswanya. Selain kantin, yang menjadi pemantauan adalah fasilitas yang ada disekitar lingkungan sekolah yang dapat mendukung kesehatan warga sekolah seperti ruang kelas, perpustakaan, ruang laboratorium. Dengan memantau dan menjaga kebersihan dan kesehatannya maka hal ini juga dapat menjadi daya tarik dan minat siswa untuk menggunakannya. Selain itu penjagaan lingkungan fisik lainnya yakni seperti ketersediaan dan pemeliharaan air bersih dan kamar mandi, adalah hal yang harus benar-benar diperhatikan oleh pihak sekolah, karena ini merupakan hal yang tak kalah penting dalam menunjang kesehatan siswa. Mengingat pentingnya apa yang menjadi kosumsi dan hal yang berkontak langsung dengan warga sekolah, khususnya siswa atau remaja, maka perlu pemantauan yang lebih ekstra dan teliti, seperti halnya dalam pemantauan air yang digunakan oleh siswa dan kamar mandi sebagai fasilitas yang utama dan tidak dapat terpisahkan begitu saja dalam kehidupan sehari-hari. Maka hal ini harus benar-benar diperhatikan. Lingkungan fisik lainnya yang tak kalah penting adalah ketersediaan bak sampah atau saluran limbah lainnya, yang dapat menjadi sumber penyakit tercepat dalam lingkungan sekolah bila tidak terjaga kebersihannya, sama halnya dengan ketersediaan kebun sekolah yang asri serta adanya tempat ibadah, yang merupakan penunjang utama dalam sekolah. Hal ini sebagai salah satu penunjang kegiatan belajar mengajar, karena apa yang siswa lihat itu yang akan tertanam dalam pikirannya. Seperti halnya dengan adanya kebun asri di lingkungan sekolah yang bisa digunakan sebagai media pembelajaran 
siswa, seperti dalam pembelajaran nama tanaman dan bahasa latinnya. Hal ini dapat juga digunakan sebagai media pembelajaran obat-obatan tradisional. Seperti tanaman rambat yang memiliki fungsi ganda, yakni sebagai hiasan dan sebagai obat-obatan tradisional. Dengan adanya media pembelajaran langsung dan nyata, ini dapat lebih lama diingat oleh siswa dan dapat lebih diaplikasikan dalam kehidupan kedepannya.

Menurut hasil penelitian, masing-masing sekolah telah menerapkan pelayanan kesehatan, pendidikan kesehatan dan pembinaan lingkungan sekolah. Dimana dalam pelaksanaan ini pihak sekolah juga menerapkan kemitraan atau kerjasama dengan pihak-pihak terkait.

Secara teori Tim Pembina UKS, maka dalam pelaksanaan UKS perlu adanya tiga hal penting yakni, pendidikan kesehatan, pelayanan kesehatan dan pembinaan lingkungan sekolah. Hal ini menjadi penilaian dan hal penting yang menggambarkan sejauh mana proses pelaksanaan UKS dapat berjalan.

Menurut analisis peneliti, sudah ada kesesuaian antara hasil penelitian dan teori yang ada bahwa benar indikator keberhasilan pelaksanaan UKS adalah berada di tiga kunci pokok yakni pendidikan kesehatan, pelayanan kesehatan dan pembinaan lingkungan sekolah. Terutama dalam hal pelayanan kesehatan yang dilakukan oleh petugas kesehatan terlatih dan tersertifikasi serta adanya peran pembimbingan secara maksimal dari guru pembina UKS yang sudah terlatih dan tersertifikasi, karena disinilah sebenarnya pokok pelaksanaan trias UKS sendiri. Karena dengan adanya keterampilan dan sertifikasi pelayanan dapat lebih terfokus dan maksimal, terutama untuk remaja SMP yang notabennya adalah masa peralihan dari anak-anak menuju masa dewasa muda dimana mereka masih dalam masa mencari jati diri mereka. Bila hal ini tidak mereka dapatkan dari lingkungan sekolah, maka yang dikhawatirkan mereka akan mencari tahu sendiri demi memuaskan rasa ingin tahu mereka. Hal ini lah yang kemungkinan besar dapat membawa remaja jatuh pada narkoba dan seks bebas. Pendidikan kesehatan juga menjadi titik pemberian informasi yang mendalam bagi siswa, karena mereka masih mencari-cari informasi yang benar tentang kehidupan bermasyarakat dini.Dalam hal ini, peran dari konselor sebaya dirasa cukup memegang peranan penting, karena pada masa ini, remaja masih lebih mempercayai teman sebayanya dibandingkan orang dewasa disekitarnya. Karena mereka merasa masih perlu untuk berkonsultasi dengan teman yang tepat. Kesempatan ini dapat diambil oleh petugas UKS dan guru untuk pendekatan kepada siswa, misalnya dengan memberikan informasi dan pengetahuan kepada mereka tentang kesehatan, selain itu bisa juga memberikan informasi tentang pengenalan terhadap tubuh dan diri mereka sendiri, dengan harapan nantinya remaja bisa lebih terbuka tidak hanya pada teman sebayanya tetapi juga kepada petugas UKS atau guru dan guru BK. Bila ketiga hal ini dapat berjalan dengan baik maka dapat dikatakan pelaksanaan UKS sekolah tersebut juga baik. Selain itu pelaksanaan kerjasama dengan pihak-pihak terkait atau kemitraan dapat menjadi titik ukur berjalannya kerjasama dan pembinaan sekolah yang sehat.

\section{SIMPULAN}

1. Pada indikator pendidikan kesehatan pada UKS di Tingkat SMP se-Kota Bandar Lampung bahwa sudah ada kesesuaian dan berjalan dengan baik. Hanya saja pada peran puskesmas terkait pembinaan pendidikan kesehatan di UKS yang masih kurang.

2. Pada indikator Pelayanan kesehatan pada UKS di Tingkat SMP se-Kota Bandar Lampung bahwa sudah sesuai dengan indikator yang disusun dalam program masing-masing sekolah. Hanya saja pada pembinaan dan pelaksanaan program KKR (Konseling Kesehatan Remaja), perlu adanya penyosialisasian lagi. Selain itu kurang terlatihnya petugas UKS tentang penanganan penyakit atau kecelakaan, seperti halnya penanganan pada keracunan makanan dan lain sebagainya.

3. Pada indikator pembinaan lingkungan sekolah yang sehat pada UKS di Tingkat SMP se-Kota Bandar Lampung sudah sesuai dengan tujuan sekolah untuk menjadikan sekolah sehat, terutama dari area kantin dan tempat pembuangan limbah. Hanya saja dibeberapa sekolah perlu disediakan keran air dan sabun cuci tangan di depan kelas.

\section{SARAN}

1. Bagi Puskesmas dalam hal pendidikan kesehatan, perlu adanya pembinaan yang lebih kepada sekolah-sekolah dibawah binaannya. Mungkin dapat dilakukan dengan cara peningkatan intensitas pemberian penyuluhan kepada siswa khususnya dan warga sekolah umumnya, dapat juga menggunakan metode-metode pendekatan dengan cara diskusi berkelompok, tanya 
jawab, media pendidikan kesehatan tidak hanya seputar poster dan leaflet.

2. Bagi puskesmas dalam hal pelayanan kesehatan, perlu adanya peningkatan dalam pembinaan program KKR (Konseling Kesehatan Remaja), mengingat pentingnya peran KKR tidak hanya dalam memberikan pelayanan di UKS, tetapi juga dalam peningkatan pendidikan kesehatan. Selain itu dapat juga diberikan pelatihan-pelatihan pada petugas kesehatan dalam hal pemberian pelayanan kegawatdaruratan dan penyakit. Seperti misalnya dalam penanganan keracunan makanan dan lain sebagainya.

3. Bagi sekolah dalam hal pembinaan lingkungan sekolah yang sehat, perlu penyediaan keran cuci tangan dan sabun di depan kelas-kelas, hal ini dimaksudkan agar warga sekolah terutama siswa dan guru dapat membiasakan cuci tangan sebelum masuk kelas. Selain itu, kebersihan dan kenyamanan fasilitas lainnya harus lebih terarah dan terpantau, karena hal ini menjadi pokok perhatian dalam kesehatan warga sekolah.

\section{DAFTAR PUSTAKA}

Badan Penelitian dan Pengembangan Kesehatan Kemenkes RI. 2013. Riskesdas 2013. Jakarta: Badan Penelitian dan Pengembangan Kesehatan Kementerian Kesehatan RI.

Departemen Kesehatan. 2011. Usaha Kesehatan Sekolah. Jakarta: Percetakan Negara.

Dinas Kesehatan Provinsi Lampung. 2011. Profil Dinas Kesehatan Provinsi Lampung. Lampung.

Kementrian Pendidikan Nasional. 2011. Pedoman Pelaksanaan UKS di Sekolah. Jakarta: Kementrian Pendidikan Nasional.
4. Bagi instansi-instansi pembina UKS agar dapat melakukan hal-hal sebagai berikut:

a. Sekretariat Kota Bandar Lampung diharapkan dapat memberi masukan dalam hal pengontrolan masing-masing sekolah melalui dinas-dinas terkait.

b. Dinas Pendidikan Kota Bandar Lampung diharapkan dapat lebih intern dalam memantau setiap sekolah, terutama dalam hal pembinaan UKS terkait pemantauan pendidikan kesehatan dan media promosinya.

c. Kementrian Agama Kota Bandar Lampung diharapkan dapat lebih memantau kemajuan kesehatan dan pemanfaatan UKS dalam dengan melalui pendekatan Imtaq.

d. Dinas Kesehatan Kota Bandar Lampung diharapkan dapat meningkatkan pemantauan terhadap Puskesmas tentang kelanjutan dalam pembinaan ilmu baru dalam bidang kesehatan. Terutama peningkatan dalam pembinaan KKR (Kader Kesehatan Remaja).

Ramawati, D., \& Purnawan, I. 2007. Pelaksanaan Trias Usaha Kesehatan Sekolah di Sekolah Menengah Pertama di Wilayah Kecamatan Purwokerto Kabupaten Banyumas. Jurnal Keperawatan Soedirman, 2(2), 95-101.

Sitepu, H., Ratag, G. A., \& Siagian, I. T. 2015. Peran Serta Masyarakat Sekolah Dalam Pelaksanaan Progam USAha Kesehatan Sekolah Di SMP Negeri 1 Manado. Jurnal e-Biomedik, 3(3). 